\title{
Pengaruh Sudut Kemiringan Head Turbin Ulir dan Daya Putar Turbin Ulir dan Daya Output Pada Pembangkit Listrik Tenaga Mikro Hidro
}

\author{
I Putu Juliana ${ }^{1}$, Antonius Ibi Weking ${ }^{2}$, Lie Jasa ${ }^{3}$
}

\begin{abstract}
The dependence of power plants on energy sources such as diesel, natural gas and coal is almost $75 \%$, encouraging the development of renewable energy in an effort to meet the electricity supply. One of them is the micro hydro power plant by utilizing the potential of existing water. The working principle of PLTMH is to change the potential energy of water into electrical energy. In this final project has been designed modeling of micro hydro power plant by using screw turbine (Archimedes Screw). The turbine used resembles a drill bit, with a diameter of a turbine of 26 $\mathrm{cm}$, a screw width of $10 \mathrm{~cm}$, and an amount of 10 pieces of blade. Measurements made on the modeling of micro hydro power plants include: water discharge, turbine rotation, generator rotation, voltage, current, torque and generator output power and efficiency. The parameters are measured by changing the water fall on the turbine from the position of the turbine head angle $0^{\circ}, 10^{\circ}, 15^{\circ}, 20^{\circ}$, $25^{\circ}, 30^{\circ}, 35^{\circ}, 40^{\circ}, 45^{\circ}, 50^{\circ}, 55^{\circ}, 60^{\circ}, 70^{\circ}, 80^{\circ}$ and $90^{\circ}$. The result of measurement that has been done on the parameters of micro hydro power plant modeling, obtained the highest measurement result at the corner of turbine head $40^{\circ}$. The output power generated is 10.92 watts, torque is $0.60 \mathrm{Nm}$ and efficiency of $14 \%$. The results obtained are still low because the turbine rotation is less able to rotate the generator, where the generator torque is greater than the torque in the turbine. This is influenced by the small water discharges in the modeling of this micro hydro power plant.
\end{abstract}

Intisari- Ketergantungan pembangkit listrik terhadap sumber energi seperti solar, gas alam dan batubara yang hampir mencapai $75 \%$, mendorong dikembangkannya energi terbarukan sebagai upaya untuk memenuhi pasokan listrik. Salah satunya adalah pada pembangkit listrik tenaga mikro hidro dengan memanfaatkan potensi air yang ada. Prinsip kerja PLTMH adalah dengan cara merubah energi potensi air menjadi energi listrik. Pada tugas akhir ini telah dirancang pemodelan pembangkit listrik tenaga mikro hidro dengan menggunakan turbin ulir (Archimedes Screw). Turbin yang digunakan memiliki menyerupai mata bor, dengan diameter turbin $26 \mathrm{~cm}$, lebar screw $10 \mathrm{~cm}$, dan jumlah sudu 10 buah.

Pengukuran yang dilakukan pada pemodelan pembangkit listrik tenaga mikro hidro ini, meliputi : debit air, putaran turbin, putaran generator, tegangan, arus, torsi serta daya output generator dan efisiensi.Parameter - parameter tersebut diukur dengan cara merubah jatuhnya air pada kincir dari posisi sudut head turbin $0^{0}, 10^{0}, 15^{\circ}, 20^{\circ}, 25^{\circ}, 30^{\circ}, 35^{\circ}, 40^{\circ}, 45^{\circ}, 50^{\circ}, 55^{\circ}, 6^{\circ}$, $70^{\circ}, 80^{\circ}$ dan $90^{\circ}$. Hasil pengukuran yang telah dilakukan terhadap parameter - parameter pemodelan pembangkit listrik

\footnotetext{
${ }^{1}$ Mahasiswa Program Studi Teknik Elektro Fakultas Teknik Universitas Udayana, Jl. Raya Penarungan, Br. Blungbang, Penarungan, Kec.Mengwi, Kab. Badung, Bali 80351 INDONESIA tlp:085738458749; e-mail: putu_juliana22@yahoo.com

${ }^{2,3}$ Dosen, Program Studi Teknik Elektro Fakultas Teknik Universitas Udayana, Jln. Kampus Bukit Jimbaran 80361 INDONESIA, telp: 0361-703315; fax: $0361-703315$ e-mail: tony@unud.ac.id, liejasa@unud.ac.id
}

tenaga mikro hidro ini, diperoleh hasil pengukuran tertinggi pada sudut head turbin $40^{\circ}$. Daya output yang dihasilkan adalah 10.92 watt, torsi adalah $0.60 \mathrm{Nm}$ dan efisiensi sebesar $14 \%$. Hasil yang diperoleh masih rendah dikarenakan putaran turbin kurang mampu untuk memutar generator, dimana torsi generator lebih besar dari torsi pada turbin. Hal tersebut dipengaruhi oleh debit air yang kecil pada pemodelan pembangkit listrik tenaga mikro hidro ini.

Kata Kunci- PLTMH, Turbin Ulir, Debit Air, Torsi, Efisiensi, Archimedes Screw

\section{Pendahuluan}

Kebutuhan akan sumber energi dari minyak bumi dan batu bara meningkat sepanjang waktu, sedangkan cadangan energinya terus menurun. Hal itu menyebabkan banyak negara yang sudah melakukan penelitian-penelitian tentang pusat pembangkit energi terbarukan. Pembaharuan atau Renewable energy merupakan penelitian yang sangat tepat untuk dikembangkan untuk mengatasi kelangkaan energi.[1]

Sumber alam Indonesia yang sangat berpotensi sebagai pembangkit listrik adalah sumber energi air, mengingat Indonesia memiliki kekayaan hutan dan sungai yang sangat banyak. Namun penelitian yang berkaitan dengan air telah menghabiskan biaya yang sangat besar karena lokasi dan investasinya yang sangat besar dan pembangunannya yang cukup lama. Solusi yang tepat untuk permasalahan investasi pembangkit listrik tenaga air yang terbilang cukup mahal adalah menggunakan Pembangkit Listrik Tenaga Mikro Hydro.[2]

Penelitian yang akan dibahas adalah PLTMH dengan menggunakan turbin ulir yang mengacu pada penelitian sebelumnya yang meneliti sudut head turbin ulir pada $25^{\circ}, 35^{\circ}$ dan $45^{\circ}$ [3], sedangkan pada penelitian ini meneliti sudut head turbin ulir dari $0^{\circ}$ sampai dengan $90^{\circ}$, sehingga hasil pengukuran lebih akurat dari penelitian sebelumnya. Turbin ini beroperasi dengan putaran rendah dan masih tergolong baru di Indonesia. Khususnya di Bali telah dibangun Pembangkit listrik Tenaga Mikro Hidro dengan turbin ulir yang dibangun di kawasan pariwisata Jatiluwih, Kabupaten Tabanan. Namun penelitian pembakitan yang dibangun di alam bebas lebih susah dilakukan karena adanya beberapa faktor yang menghambat seperti faktor alam, faktor lingkungan, faktor ekonomi maupun faktor adat istiadat. Maka dari itu peneliti tertarik untuk membuat Prototipe Pembangkit Listrik Tenaga Mikro Hydro dengan turbin ulir berskala laboratorium guna mengembangkan PLTMH dengan turbin ulir dan kepentingan praktikum. Turbin ulir memiliki beberapa keunggulan diantara turbin-turbin air yang lainnya seperti dapat dioperasikan pada head rendah. 
Kinerja turbin ulir ini dipengaruhi oleh parameterparameter dan salah satu parameter yang penting dalam pengoperasian turbin tersebut adalah kemiringan dari turbin tersebut, kemiringan turbin sangat berpengaruh terhadap putaran turbin yang berpengaruh terhadap putaran generator dan berdampak pada daya output generator itu sendiri. Berdasarkan uraian diatas, penulis tertarik mengembangkan penelitian tentang turbin ulir yang bertujuan untuk mengetahui pengaruh sudut kemiringan terhadap daya putar turbin ulir dan daya output pada Pembangkit Listrik Tenaga Miko Hydro (PLTMH).

\section{KEMIRINGAN TURBIN}

\section{A. Kemiringan}

Posisi kemiringan yang tajam dengan maksud agar diperoleh kecepatan dan tekanan air yang tinggi untuk memutar turbin, semakin besar tekanan atau kecepatan air maka daya putar turbin akan semakin cepat yang sangat berpengaruh terhadap daya output yang akan dihasilkan oleh generator.Seperti pada gambar 1.[3]

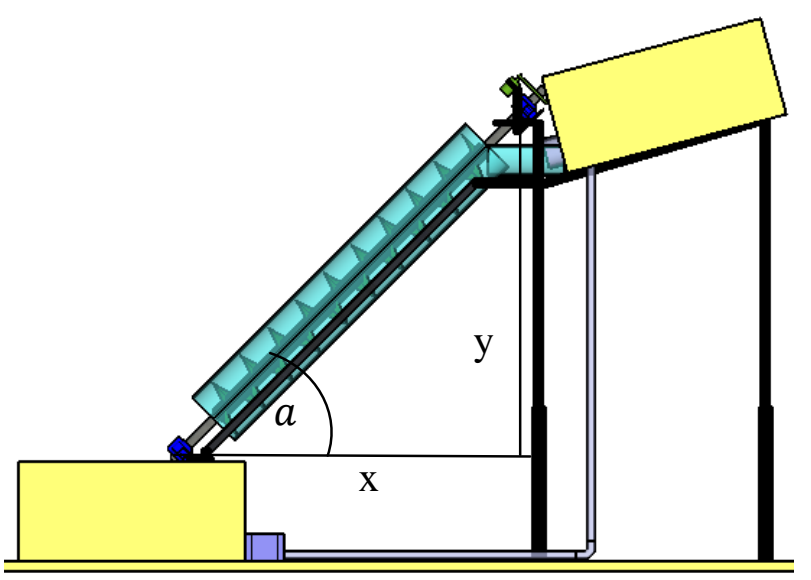

Gambar 1: Kemiringan Head turbin Ulir

Derajat kemiringan dapat ditentukan dengan persamaan : $\tan \alpha=y / x \quad \alpha=\tan ^{-1}(y / x)$

Dimana :

$$
\begin{aligned}
\operatorname{Tan} \alpha & =\text { derajar kemiringan } \\
\mathrm{y} & =\text { jarak vertikal } \\
\mathrm{x} & =\text { jarak horizontal }
\end{aligned}
$$

\section{B. Pembangkit Tenaga Air}

Pembangkit tenaga air adalah suatu bentuk perubahan tenaga dari tenaga air dengan ketinggian dan debit tertentu menjadi tenaga listrik, dengan menggunakan turbin air dan generator. Daya (power) yang dihasilkan dapat dihitung berdasarkan rumus berikut :[4]

Dimana :

$$
P=\rho \cdot Q \cdot h \cdot g
$$

\footnotetext{
$\mathrm{P} \quad=$ daya keluaran secara teoritis (watt)

$\rho \quad=$ massa jenis fluida $\left(\mathrm{kg} / \mathrm{m}^{3}\right)$

$\mathrm{Q}=$ debit air $\left(\mathrm{m}^{3} / \mathrm{s}\right)$

$\mathrm{h}=$ ketinggian efektif $(\mathrm{m})$

$\mathrm{g} \quad$ = gaya gravitasi $\left(9.8 \mathrm{~m} / \mathrm{s}^{2}\right)$
}

Daya yang dihasilkan pada pemodelan PLTMH dengan turbin ulir dapat dihitung dengan persamaan :[5]

$$
\text { Pout }=\text { V.I }
$$

Dimana :

$$
\begin{aligned}
\text { Pout } & =\text { Daya Keluar (watt) } \\
\mathrm{V} & =\text { Tegangan (Volt) } \\
\mathrm{I} & =\text { Arus (A) }
\end{aligned}
$$

\section{Pembangkit Listrik Tenaga Mikro Hidro}

Pembangkit Listrik Tenaga Mikrohidro (PLTMH), adalah suatu pembangkit listrik skala kecil yang menggunakan tenaga air sebagai tenaga penggeraknya seperti, saluran irigasi, sungai atau air terjun alam dengan cara memanfaatkan tinggi terjunan (head) dan jumlah debit air. Prinsip dasar mikrohidro adalah memanfaatkan energi potensial yang dimiliki oleh aliran air pada jarak ketinggian tertentu dari tempat instalasi pembangkit listrik. Sebuah skema mikrohidro memerlukan dua hal yaitu, debit air dan ketinggian jatuh (head) untuk menghasilkan tenaga yang dapat dimanfaatkan. Hal ini adalah sebuah sistem konversi energi dari bentuk ketinggian dan aliran (energi potensial) ke dalam bentuk energi mekanik dan energi listrik. [6]

\section{Turbin Air}

Turbin air mengubah energi potensial air menjadi energi mekanis. Energi mekanis diubah dengan generator listrik menjadi tenaga listrik. Berdasarkan prinsip kerja turbin dalam mengubah energi potensial air menjadi energi mekanis. Berikut merupakan klarifikasi turbin air untuk PLTMH :

1) Turbin impuls adalah turbin air yang cara bekerjanya dengan merubah seluruh energi air (yang terdiri dari energy potensial + tekanan + kecepatan) yang tersedia menjadi energi kinetic untuk memutar turbin, sehingga menghasilkan energi puntir. Contohnya : Turbin Pelton, Turbin Turgo Dan Turbin Crossflow.

2) Turbin reaksi adalah turbin air yang cara bekerjanya dengan merubah seluruh energi air yang tersedia menjadi energi puntir. Contohnya : Turbin Prancis dan Turbin Kaplan[7]

Pemilihan jenis turbin dapat diperhitungkan dengan mempertimbangkan parameter - parameter khusus yang mempengaruhi sistem operasi turbin, yaitu :

1) Faktor tinggi jatuhnya air efektif (net head) dan debit yang akan dimanfaatkan untuk operasi turbin.

2) Faktor daya (power) yang diinginkan berkaitan dengan head dan debit yang tesedia, untuk menghitung debit pada pemodelan PLTMH ini digunakan rumus :

$$
\text { Debit }=\frac{\text { Volume bejana }}{\text { Waktu untuk memenuhi bejana }}
$$

3) Kecepatan (putaran) turbin yang akan ditransmisikan ke generator.

4) Untuk memutar generator diperlukan torsi turbin yang sama dengan torsi generator. Untuk torsi dapat dilakukan dengan perhitungan :[8]

$$
P=T x 2 \pi \times \frac{N}{60}
$$


Dimana :

$$
T=\frac{P}{2 \pi \frac{n}{60}}
$$

$\mathrm{T} \quad=$ Torsi $(\mathrm{Nm})$

$P \quad=$ daya $(\mathrm{kW})$

$N \quad=$ kecepatan putaran turbin

5) Dalam sebuah pembangkit listrik harus diketahui efisiensi dari pemakaian turbin yang berbeda. Untuk menentukan efisiensi digunakan persamaan :[9]

$$
\eta=\frac{\text { Pout }}{\text { Pin }} \times 100 \%
$$

\section{E. Turbin Archimedes Screw}

Turbin Archimedes screw merupakan salah satu turbin yang sangat special karena dapat beroperasi pada daerah yang memiliki head yang sangat rendah, seperti pada gambar 2 . Pada penggunaannya turbin screw ini posisinya tergantung dari kondisi head yang ada di lapangan.Turbin screw bekerja pada head rendah dengan ketinggian air jatuh antara $2-15$ m .[10]

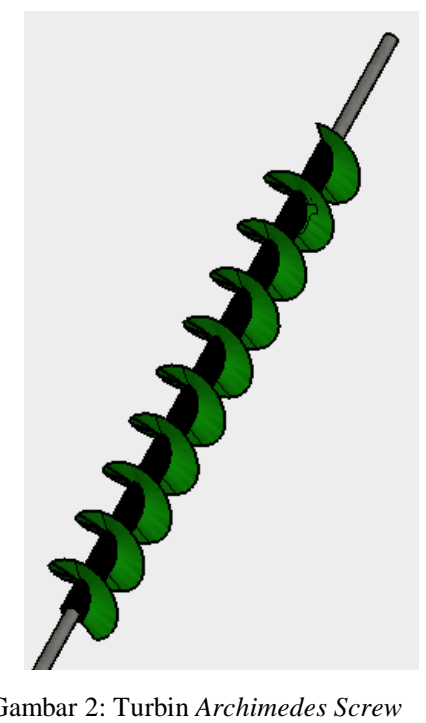

Adapun beberapa keunggulan dari turbin Archimedes Screw dibandingkan dengan jenis turbin air lainnya yaitu:[11]

a. Baik dikembang pada daerah yang memiliki sumber air dengan debit yang cukup besar (sungai) namun hanya memiliki head yang rendah.

b. Tidak memerlukan sistem merlukan system kontrol yang sangat rumit seperti turbin lainnya.

c. Tekanan air yang terjadi pada tidak merusak ekologi dalam hal ini dampak terhadap makhluk hidup air (ikan).

d. Tidak membutuhkan draft tube, sehingga dapat mengurangi pengeluaran untuk penggalian pemasangan draft tube.

e. Memiliki efisiensi yang tinggi, dengan variasi debit yang besar dan sangat baik untuk debit air yang kecil.

f. Tidak memerlukan jaring-jaring halus sebagai pencegah masuknya puing-puing ke

dalam turbin, sehingga dapat mengurangi biaya perawatan.

\section{Metode PenELITIAN}

I Putu Juliana : Pengaruh Sudut Kemiringan Head...

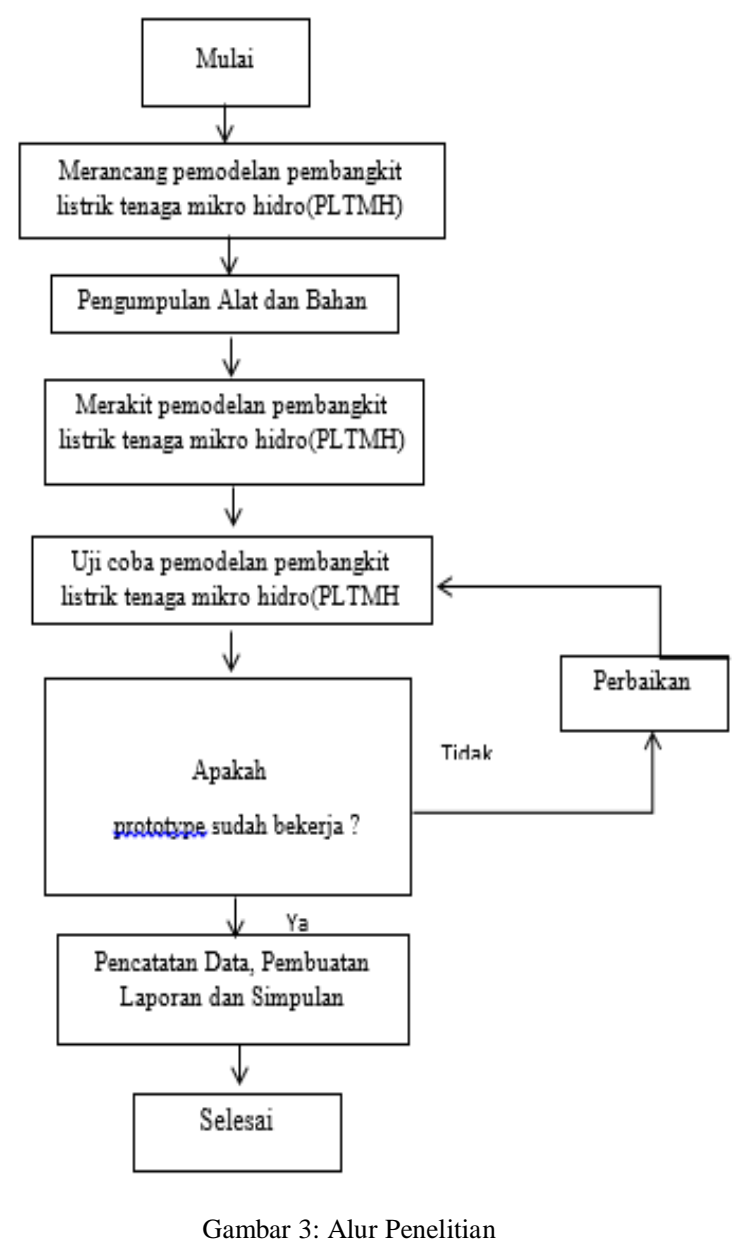

A. Studi Pustaka

Mencari refrensi-refrensi dari jurnal-jurnal, artikel, dan buku-buku yang berhubungan dengan objek penelitian.

B. Pembuatan Rancangan Model Sistem PLTMH

Merancang sistem PLTMH dan merancang desain turbin yang akan digunakan pada penelitian ini. Berikut merupakan tabel perencanaan yang dapat dilihat pada tabel 1 dan tabel 2 mengenai sistem pemodelan PLTMH dan turbin pada penelitian ini :

TABEL I

\begin{tabular}{|c|c|}
\hline \multicolumn{2}{|c|}{ PERENCANAAN SISTEM } \\
\hline Parameter & Value \\
\hline Volume Box & 220 liter \\
\hline Head Netto & $190 \mathrm{~cm}$ \\
\hline Panjang rumah turbin & $150 \mathrm{~cm}$ \\
\hline Diameter rumah turbin & $27 \mathrm{~cm}$ \\
\hline Diameter pipa & $7,6 \mathrm{~cm}$ \\
\hline
\end{tabular}

TABEL II

PERENCANAAN TURBIN

\begin{tabular}{|c|c|}
\hline Parameter & Value \\
\hline Diameter turbin & $26 \mathrm{~cm}$ \\
\hline Jari-jari turbin & $13 \mathrm{~cm}$ \\
\hline
\end{tabular}

p-ISSN:1693 - 2951; e-ISSN: 2503-2372 


\begin{tabular}{|c|c|}
\hline Tebal sudu screw & $0,25 \mathrm{~cm}$ \\
\hline Jarak setiap sudu screw & $15 \mathrm{~cm}$ \\
\hline Lebar sudu screw & $10 \mathrm{~cm}$ \\
\hline Jumlah sudu screw & 1 buah \\
\hline Jumlah lilitan screw & $10 \mathrm{buah}$ \\
\hline Sudut sudu screw & $24^{\circ}$ \\
\hline Diameter poros utama & $2,5 \mathrm{~cm}$ \\
\hline Diameter poros luar & $6 \mathrm{~cm}$ \\
\hline Panjang poros utama & $215 \mathrm{~cm}$ \\
\hline Panjang poros luar & $150 \mathrm{~cm}$ \\
\hline Berat turbin & $24 \mathrm{~kg}$ \\
\hline
\end{tabular}

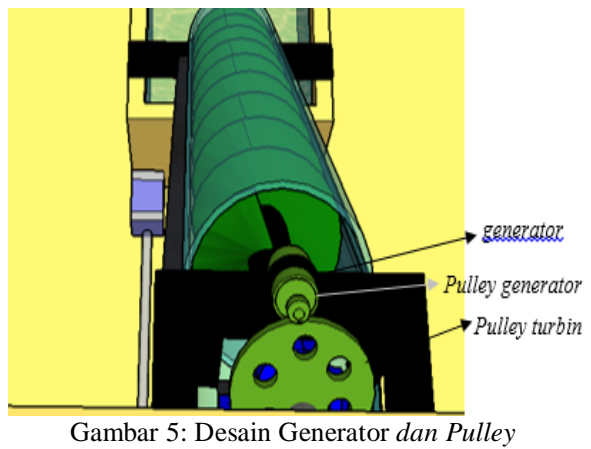

\section{Menyiapkan Alat Dan Bahan}

Alat-alat yang perlu disiapkan seperti besi, selang, pipa, penempatan box

\section{Perakitan PLTMH}

Komponen yang dirakit berupa rangka PLTMH, Turbin, generator, saluran air, box. Pemodelannya seperti gambar 4

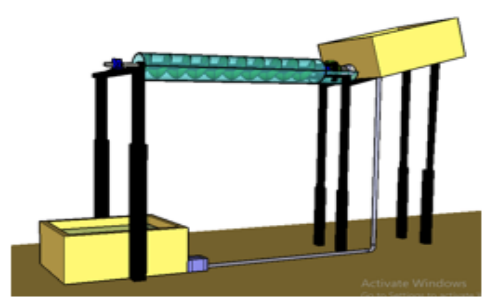

(a)

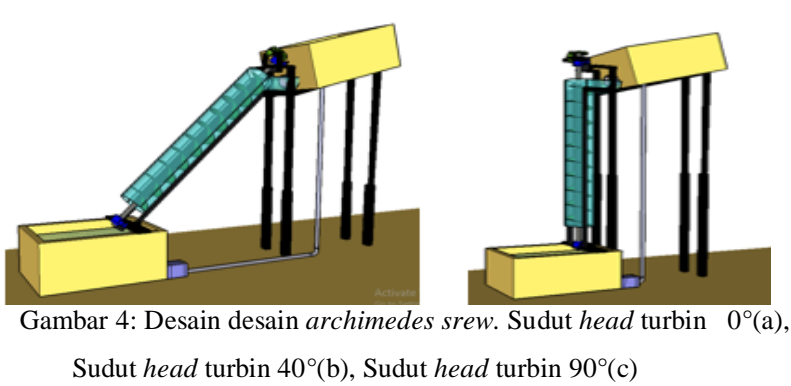

\section{E. Pengujian Pemodelan PLTMH}

Cara kerja dari pemodelan ini berupa pompa akan menghisap air yang terdapat pada bak, kemudian air dialirkan melalui pipa sampai ke bak penampungan air yang dipasang pada Head turbin ditampung kembali pada bak. Kemudian air dialirkan ke bilah-bilah turbin dan turbin berputar sehingga terjadi energi mekanik tubin berputar, turbin terhubung dengan pulley turbin melalui sebuah poros. Dengan sebuah belt, pulley turbin dihubungkan dengan pulley yang terhubung pada rotor generator (pulley generator).

Putaran yang terjadi pada turbin akan memutar generator melalui kedua pulley yang terhubung. Generator akan merubah energi mekanik dari turbin menjadi energi listrik. Untuk mengukur putaran turbin dan generator dipergunakan tachometer. Sedangkan voltmeter dan amperemeter dipergunakan untuk mengukur tegangan dan arus yang dihasilkan oleh generator.

\section{F. Mencatat dan Menganalisa Data}

Setelah melakukan pengujian maka didapatkan data hasil berupa putaran (rpm), tegangan dan arus yang akan dianalisis dan digunakan untuk menjelaskan pengarus kemiringan head turbin terhadap daya putar turbin, tegangan, arus dan daya output dari pemodelan PLTMH dengan turbin ulir. Analisis data dalam penelitian ini menggunakan data kuantitatif. Data kuantitatif dalam penelitian ini yaitu diperoleh dari hasil setiap pengujian dimana dilakukan pengujian sebanyak 5 kali pengukuran setiap parameter agar mendapatkan hasil yang akurat dengan variasi sudut kemiringan head turbin Ulir yang berbeda.

\section{HASIL DAN PEMBAHASAN}

\section{A. Pembangkit Listrik Tenaga Mikro Hidro}

Pemodelan Pembangkit Listrik Tenaga Mikro Hidro (PLTMH) adalah suatu pemodelan pembangkit listrik yang penggerak utamanya menggunakan tenaga air. Cara kerja sistem PLTMH ini diawali dengan pompa menghisap air yang terdapat pada bak bawah, kemudian air dialirkan melalui selang sampai ke bak atas, kemudian air yang ada dibak mengalir turun ke talang air yang dipasang turbin ulir di dalam talang air kemudian turbin dapat berputar. Dapat dilihat pada gambar 5. Terjadi energi mekanik saat turbin berputar, turbin terhubung dengan gear turbin melalui sebuah poros. Dengan dipasang gear pada turbin dan generator yang terhubung pada rotor generator. Pengukuran parameter - parameter pada pemodelan pembangkit listrik tenaga mikro hidro akan dilakukan dengan mengganti sudut head turbin berturut - turut dari $0^{\circ}, 10^{\circ}, 15^{\circ}, 20^{\circ}, 25^{\circ}, 30^{\circ}, 35^{\circ}, 40^{\circ}, 45^{\circ}, 50^{\circ}, 55^{\circ}, 60^{\circ}, 70^{\circ}$, $80^{\circ}$ dan $90^{\circ}$. Realisasi dari desain pemodelan pembangkit listrik tenaga mikro hidro secara utuh dapat dilihat pada gambar berikut. 


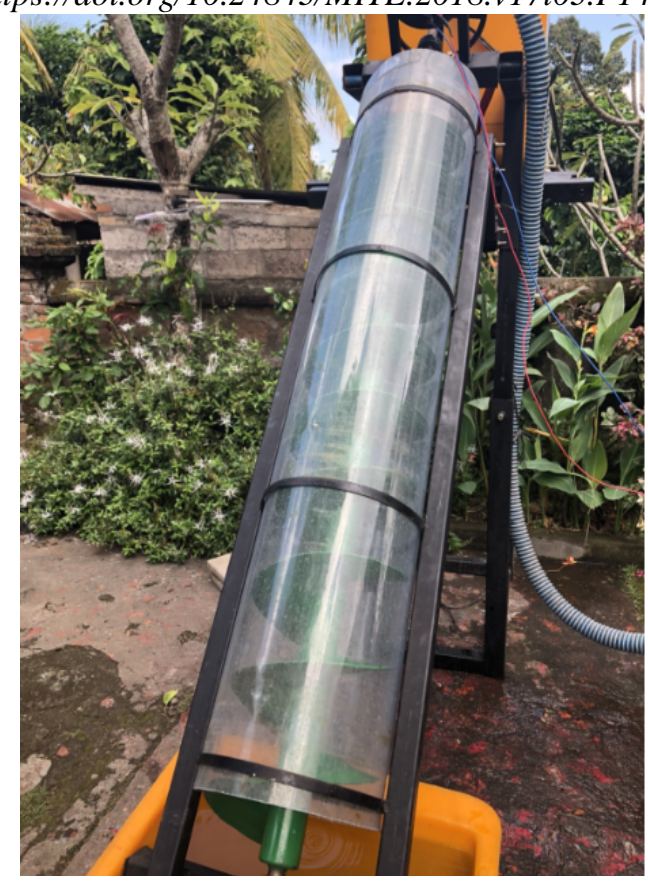

Gambar 6: Realisasi Pembangkit Listrik Tenaga Mikro Hidro

\section{B. Pengukuran Debit Air}

Debit air adalah besaran yang menyatakan banyaknya air yang mengalir selama satu detik yang melewati suatu penampang luas. Pengujian debit air bertujuan untuk mengetahui seberapa banyak air yang mengalir dalam satuan volume per waktu. Pada penelitian ini, pengukuran debit air pada pemodelan pembangkit listrik tenaga mikro hidro dilakukan dengan cara membagi volume bejana per waktu untuk memenuhi bejana.

Bejana yang digunakan untuk pengujian memiliki volume 5.9 liter, sehingga pengukuran debit dapat dihitung sebagai berikut :

$$
\begin{gathered}
\text { Debit }=\frac{\text { Volume bejana }}{\text { Waktu untuk memenuhi bejana }} \\
\begin{array}{c}
Q=\frac{220}{37} \\
Q=5,9 \mathrm{lt} / \mathrm{s}
\end{array}
\end{gathered}
$$

\section{Pengukuran Drajat Kemiringan Head Turbin}

Pengukuran derajat kemiringan ditentukan dengan mengetahui jarak vertical (y) dan jarak horizontal (x) . Berikut merupakan tabel pengukuran derajat ketinggian head turbin ulir yang terlampir pada tabel 3 dibawah ini :

TABEL III

PERHITUNGAN DRAJAT KEMIRINGAN HEAD TURBIN ULIR

\begin{tabular}{|c|c|c|}
\hline $\begin{array}{c}\text { jarak vertical }(\mathrm{y}) \\
(\mathrm{cm})\end{array}$ & $\begin{array}{c}\text { jarak horizontal }(\mathrm{x}) \\
(\mathrm{cm})\end{array}$ & \begin{tabular}{c} 
Derajat Kemiringan \\
\hline 0
\end{tabular} \\
\hline 36 & 215 & $10^{0}$ \\
\hline 55 & 205 & $15^{0}$ \\
\hline 72 & 200 & $20^{0}$ \\
\hline 89 & 195 & $25^{0}$ \\
\hline 104 & 190 & $30^{0}$ \\
\hline
\end{tabular}

I Putu Juliana : Pengaruh Sudut Kemiringan Head...

\begin{tabular}{|c|c|c|}
\hline \multicolumn{2}{|c|}{397} \\
\hline 120 & 185 & $35^{0}$ \\
\hline 134 & 180 & $40^{0}$ \\
\hline 147,5 & 175 & $45^{0}$ \\
\hline 160 & 170 & $50^{0}$ \\
\hline 173 & 155 & $55^{0}$ \\
\hline 186 & 145 & $60^{0}$ \\
\hline 196,5 & 100 & $70^{0}$ \\
\hline 205 & 65 & $80^{\circ}$ \\
\hline 215 & 0 & $90^{0}$ \\
\hline
\end{tabular}

\section{Perhitungan Daya Hidrolis Air}

Untuk mengetahui daya hidrolisis atau daya yang dihasilkan oleh air dari suatu ketinggian dihitung dari sudut $10^{\circ}$, karena pada sudut $0^{\circ}$ tidak ada ketinggian, perhitungan dapat dilakukan dengan persamaan :

$$
\begin{aligned}
& \mathrm{P}=\rho . \mathrm{Q} . \mathrm{h} . \mathrm{g} \\
& \mathrm{P}=1000 * 0,0059 * 0,36 * 9,81 \\
& \mathrm{P}=20,83 \text { watt }
\end{aligned}
$$

\section{E. Pengukuran Putaran Turbin}

Grafik dari pengukuran putaran turbin sebelum dan sesudah dikopel dengan generator dapat di lihat pada gambar 6 dan 7 diamana putaran tertinggi didapatkan pada sudut head turbin $40^{\circ}$ sebesar $303 \mathrm{rpm}$ sebelum dikopel dengan generator dan 175 rpm sesudah dikopel dengan generator.

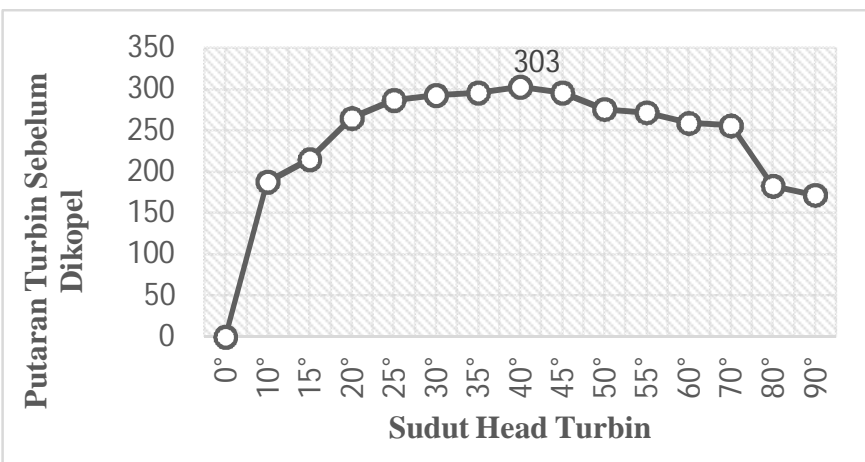

Gambar 7: Grafik Pengukuran Putaran Turbin Sebelum Dikopel Dengan Generator

Dari gambar 6 dapat diketahui semakin besar sudut head turbin bukan berarti semakin cepat pula putaran turbin yang belum dikopel dengan generator. Hal ini karena pengaruh air yang melewati turbin, jika terlalu banyak merendam turbin, maka turbin akan lambat berputar, begitu pula sebaliknya, jika turbin tidak tergenang air, turbin tidak akan berputar, jadi antara tenggelam turbin dan aliran air harus seimbang, pada sudut $40^{\circ}$, dimana air tepat mengenai daerah paling aktif pada turbin, sehingga dari gambar 6 putaran turbin sebelum dikopel dengan generator memiliki putaran tercepat pada sudut $40^{\circ}$ yaitu sebesar $303 \mathrm{rpm}$. Sedangkan pada sudut head turbin dibawah $35^{\circ}$ kebawah, kecepatan putaran turbin semakin lambat, yang dikarenakan aliran air terlalu dalam menenggelamkan turbin, dan kecepatan putaran turbin yang terukur pada sudut $35^{\circ}$ adalah $296 \mathrm{rpm}$, begitu pula pada sudut

$$
\text { p-ISSN:1693 - 2951; e-ISSN: 2503-2372 }
$$


head turbin $45^{\circ}$ keatas kecepatan putaran turbin menurun yang dikarenakan aliran air tidak mengenai bagian aktif turbin dan aliran air semakin tinggi sudut head turbin akan mengenai bagian atas turbin. Sementara untuk sudut head turbin $0^{0}$ turbin tidak berputar.

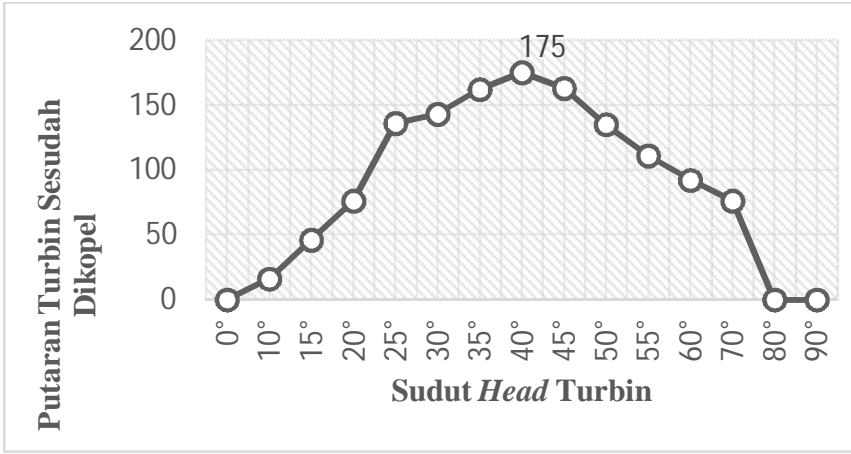

Gambar 8: Grafik Pengukuran Putaran Turbin Sesudah Dikopel Dengan Generator

Darigambar 7 dapat diketahui sudut head turbin $40^{\circ}$ memiliki kecepatan putaran turbin sesudah dikopel dengan generator tertinggi yaitu $175 \mathrm{rpm}$, itu dikarenakan air mengenai bagian paling aktif dari turbin dan tenggelamnya turbin juga seimbang dengan aliran air. Sedangkan pada sudut head turbin dibawah $35^{\circ}$ kebawah, kecepatan putaran turbin semakin lambat, yang dikarenakan aliran air terlalu banyak menenggelamkan turbin, dan kecepatan putaran turbin yang terukur pada sudut $35^{\circ}$ adalah $162 \mathrm{rpm}$, begitu pula pada sudut head turbin $45^{\circ}$ keatas kecepatan putaran turbin menurun yang dikarenakan aliran air tidak mengenai bagian aktif turbin dan aliran air semakin tinggi sudut head turbin akan mengenai bagian atas turbin,. Sementara pada sudut head turbin $0^{\circ}$ turbin tidak berputar karena terlalu banyak bagian turbin yang tenggelam yang menyebabkan turbin susah berputar dan pada sudut head turbin $80^{\circ}$ dan $90^{\circ}$ turbin juga tidak berputar yang dikarenakan aliran air mengenai bagian atas turbin yang mengakibatkan turbin tidak berputar. Walaupun sudah dikopel atau dibebani dengan generator putaran turbin tertinggi tetap terukur pada sudut head turbin $40^{\circ}$.

\section{F. Pengukuran Putaran Generator}

Grafik pengaruh kemiringan terdadap putaran generator dapat dilihat pada gambar 8 .

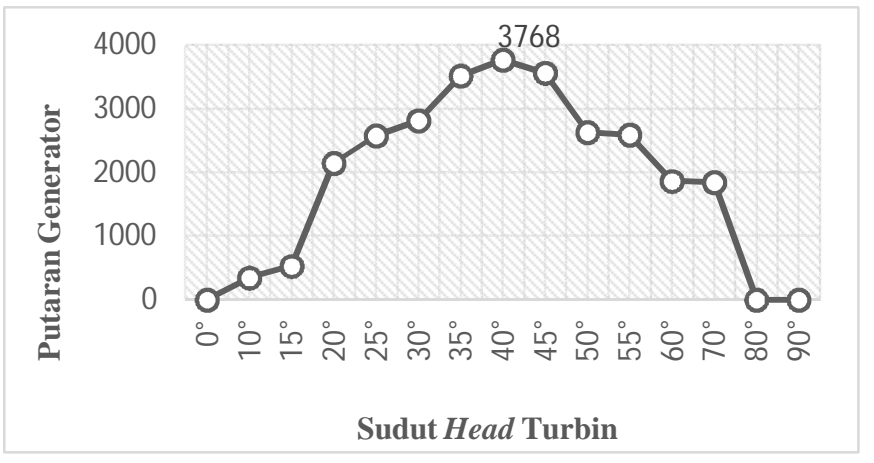

Gambar 9: Grafik Pengukuran Putaran Turbin Dengan Generator

Dari gambar 8 dapat diketahui sudut head turbin $40^{\circ}$ memiliki kecepatan putaran generator tertinggi yaitu 3768 rpm, itu dikarenakan air mengenai bagian paling aktif dari turbin dan tenggelamnya turbin juga seimbang dengan aliran air. Sedangkan pada sudut head turbin dibawah $35^{\circ}$ kebawah, kecepatan putaran generator menurun, yang dikarenakan aliran air terlalu banyak menenggelamkan turbin yang berpengaruh terhadap putaran generator, dan kecepatan putaran generator yang terukur pada sudut $35^{\circ}$ adalah 3565 rpm, begitu pula pada sudut head turbin $45^{\circ}$ keatas kecepatan putaran turbin menurun yang dikarenakan aliran air tidak mengenai bagian aktif turbin dan aliran air semakin tinggi sudut head turbin akan mengenai bagian atas turbin. Nilai tersebut didapat karena rasio pulley turbin dan pulley generator adalah 1 : 20, sehingga semakin tinggi putaran turbin semakin tinggi pula putaran generator. Sementara putaran generator terendah terukur pada sudut head turbin $10^{\circ}$ yaitu sebesar $347 \mathrm{rpm}$. Sedangkan untuk sudut head turbin $0^{0}$, $80^{\circ}$ dan $90^{\circ}$ karena turbin tidak berputar, maka generator juga tidak berputar.

\section{G. Perhitungan Daya Output Generator}

Sudut head turbin $40^{\circ}$ memiliki daya output tertinggi yaitu 10,92057 watt, namun terjadi penurunan daya output generator pada sudut head turbin $45^{\circ}$ dan sudut head turbin $45^{\circ}$. Hal tersebut dikarenakan putaran generator yang menurun pada sudut tersebut, sehingga mempengaruhi arus dan tegangan yang dihasilkan menjadi menurun. Sementara pada sudut head turbin $0^{\circ}, 10^{\circ}, 80^{\circ}$ dan $90^{\circ}$ karena generator tidak berputar maka generator tidak menghasilkan daya output. Daya output tertinggi diperoleh pada sudut head turbin $40^{\circ}$, pada sudut tersebutlah didapat putaran generator tertinggi, putaran generator tersebut berpengaruh terhadap nilai arus dan tegangan yang dihasilkan oleh generator. Dari grafik 4.4 dapat dilihat daya tertinggi diperoleh saat sudut head turbin $40^{\circ}$ dengan nilai daya 10,92057 watt. Grafik perhitungan daya output generator dapat dilihat pada gambar 9 .

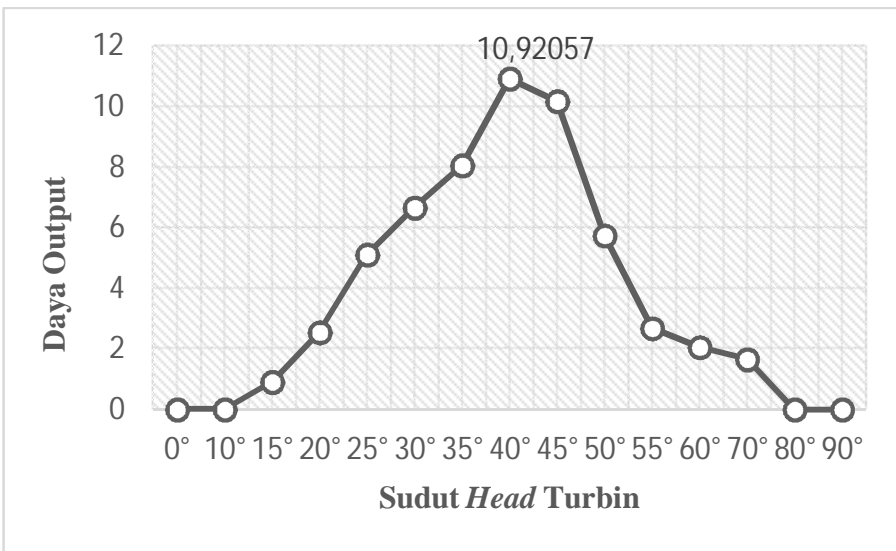

Gambar 10: Grafik Hungungan Sudut Head Turbin Dengan Daya Output Generator

\section{H. Perhitungan Torsi Generator}

Sudut head turbin $40^{\circ}$ memiliki torsi tertinggi yaitu 0,60 $\mathrm{Nm}$, namun terjadi penurunan torsi pada sudut head turbin $45^{\circ}$. Hal tersebut dikarenakan selisih antara kecepatan putaran turbin dengan kecepatan putaran generator pada sudut head turbin $45^{\circ}$ bukan yang paling tinggi. Sudut head turbin $40^{\circ}$ kecepatan putaran turbin adalah 303 rpm sedangkan kecepatan 
putaran generator adalah $3768 \mathrm{rpm}$, dan memiliki selisih tertinggi dari pada yang lain. Sehinggatorsi tertinggi diperoleh pada sudut head turbin $40^{\circ}$ yaitu sebesar $0,60 \mathrm{Nm}$. Torsi terendah diperoleh pada sudut head turbin $15^{0}$ yaitu sebesar $0.19 \mathrm{Nm}$. Sementara pada sudut head turbin $0^{0}, 10^{\circ}, 80^{\circ}$ dan $90^{\circ}$ karena dan generator tidak berputar, maka perhitungan torsi tidak dilakukan. Perhitungan untuk mendapatkan torsi dapat digunakan persamaan ;

$$
T=\frac{P}{2 \pi \frac{n}{60}}=\frac{0,91}{2 * 3,14 * \frac{46}{60}}=\frac{0,91}{4,81}=0,19 \mathrm{Nm}
$$

Untuk grafik hubungan antara sudut kemiringan head turbin dengan torsi dapat dilihat pada gambar 10 dibawah :

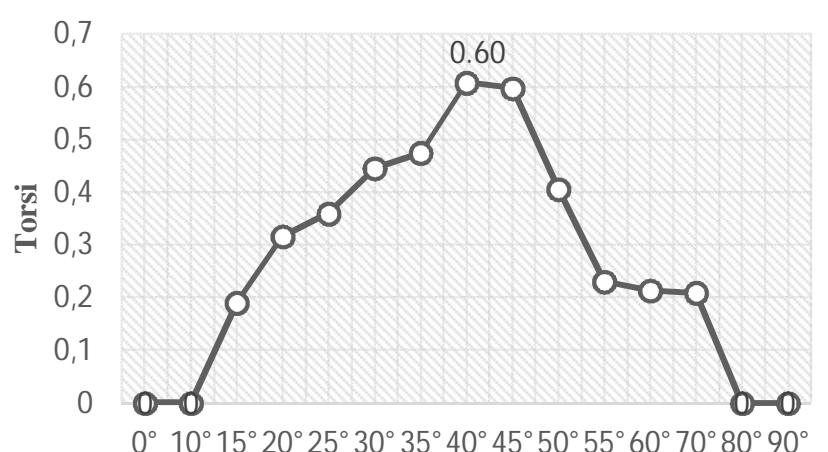

Sudut Head Turbin

Gambar 11: Grafik Hungungan Sudut Head Turbin Dengan Torsi

\section{Perhitungan Efisiensi}

Perhitungan efisiensi diperoleh dari daya output dibagi dengan daya input, maka dapat dihitung dari sudut $15^{\circ}$ dengan efisiensi sebagai berikut :

$$
\eta=\frac{0.91 \text { watt }}{31,83 \text { watt }} \times 100 \%=2.8 \%
$$

Grafik hungungan sudut kemiringan head turbin terhadap efisiensi dapat dilihat pada gambar 11 dibwah ini :

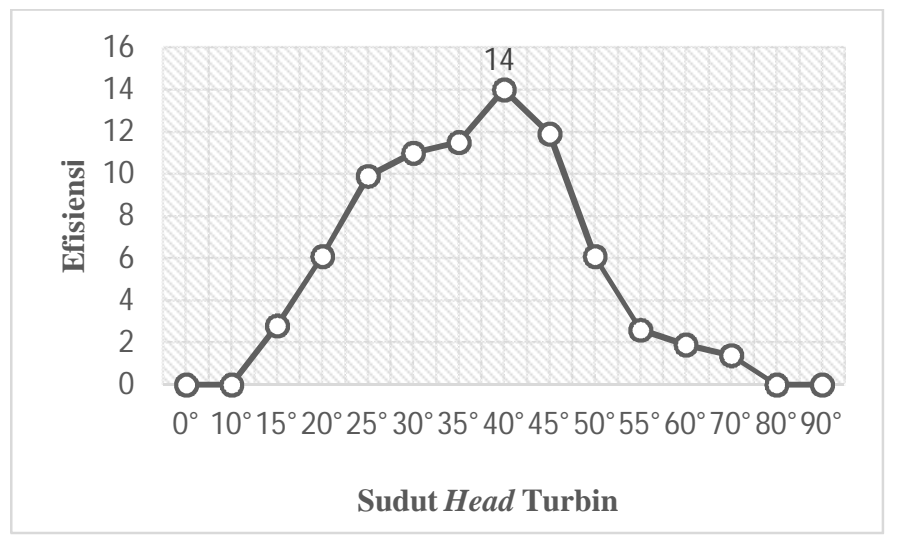

Gambar 12: Grafik Hungungan Sudut Head Turbin Dengan Efisiensi
Efisiensi terbesar pada sudut head turbin $40^{\circ}$ yaitu 0,14 , atau $14 \%$, namun terjadi penurunan efisiensi pada saat sudut head turbin $45^{\circ}$. Hal tersebut dikarenakan daya output pada saat sudut head turbin $45^{0}$ lebih kecil dari sudut head turbin $40^{\circ}$. Sedangkan efisiensi terendah diperoleh pada sudut head turbin $70^{\circ}$. Sementara untuk sudut head turbin $0^{\circ}, 10^{\circ}, 80^{\circ}$ dan $90^{\circ}$ efisiensi tidak dihitung karena pada sudut head turbin tersebut turbin dan generator dianggap tidak berputar, sehingga generator tidak menghasilkan daya output.

\section{Kesimpulan}

Simpulan yang dapat diambil berdasarkan hasil dari pengujian dan pembahasan yang telah dilakukan adalah sebagai berikut :

1. Kinerja dari pemodelan pembangkit listrik tenaga mikro hidro dengan menggunakan turbin ulir yang dibangun sangat berpengaruh terhadap tenggelamnya turbin dan jatuh air dari ujung pipa keluaran box penampungan.

2. Dalam penelitian ini sudut head turbin $40^{\circ}$ paling efektif mengasilkan putaran (rpm) terbesar sebesar 303 sebelum dikopel, 177 sesudah dikopel, putaran (rpm) generator terbesar sebesar 3768 (rpm) dan daya tertinggi adalah sudut head turbin $40^{\circ}$ sebesar 10.92 watt. Jika lebih rendah dari sudut head turbin $40^{\circ}$, maka bagian turbin akan semakin banyak yang tenggelam, sehingga putaran turbin semakin lambat, begitu pula sebaliknya, semakin tinggi sudut head turbin dari $40^{\circ}$, maka jatuh air dari ujung pipa keluaran box akan semakin mengenai bagian atas turbin.

3. Pada pemodelan pembangkit listrik tenaga mikro hidro yang dibangun menggunakan turbin ulir dengan jumlah balde 1 buah dan jumlah Screw turbin sebanyak 10 buah. Dengan sudut head turbin dari dari $0^{\circ}, 10^{\circ}, 15^{\circ}, 20^{\circ}, 25^{\circ}$, $30^{\circ}, 35^{\circ}, 40^{\circ}, 45^{0}, 50^{\circ}, 55^{\circ}, 60^{\circ}, 70^{\circ}, 80^{\circ}$ dan $90^{\circ}$, dimana efisiensi tertinggi didapat pada sudut $40^{\circ}$ sebesar $14 \%$

\section{REFERENSI}

[1] Achmad Bahri,2016, Merancang Dan Mengimplementasi Modul Praktikum Pembangkit Listrik Tenaga Mikro Hidro Di Jurusan Teknik Elektro Dan Komputer Universitas Udayana, Universitas Udayana, Bali

[2] I Wayan Budiarsana Saputra, Rancang Bangun Pemodelan Pembangkit Listrik Tenaga Mikro Hidro (Pltmh) Menggunakan Kincir Overshot Wheel, Universitas Udayana, Bali.

[3] Agung Dwi Nugroho, 2017, Kajian Teoritik Pengaruh Geometri Dan Sudut Kemiringan Terhadap Kinerja Turbin Ulir Archimedes Screw, Surakarta

[4] Subandono, A., 2012. Pembangkit Listrik Tenaga Mikro Hidro. Kediri : Universitas Pawyatan Daha Kediri

[5] T. Mirzan Syahputra, dkk, 2017, Rancang Bangun Prototipe Pembangkit Listrik Tenaga Piko Hydro Dengan Menggunakan Turbin Ulir, Universitas Syiah Kuala, Banda Aceh.

[6] Yul Hizhar,dkk, 2017, Rancang Bangun Dan Studi Eksperimental Pengaruh Perbedaan Jarak Pitch Dan Kemiringan Poros Terhadap Kinerja Mekanik Model Turbin Ulir 2 Blade Pada Aliran Head Rendah, Universitas Andalas, Padang

[7] Herman Budi Harja, dkk, 2014, Penentuan Dimensi Sudu Turbin Dan Sudut Kemiringan Poros Turbin Pada Turbin Ulir Archimedes, Institut Teknologi Bandung.

[8] Rosly, C.Z. 2016. Parametric Study On Efficiency Of Archimedes Screw Turbine. ARPN Journal of Engineering and Applied Sciences. VOL. 11, NO. 18, SEPTEMBER 2016

[9] Rorres, C. 2000. The Turn of the Screw: Optimal Design of An Archimedes Screw. Journal of Hydraulic Engineering. Philadelphia. 
[10] Adly Havendri dan Hendro Lius, 2009, Perancangan Dan Realisasi Model Prototipe Turbin Air Type Screw (Archimedean Turbine) Untuk Pembangkit Listrik Tenaga Mikrohidro Dengan Head Rendah Di Indonesia, Universitas Andalas, Kampus Limau Manis Padang.

[11] Adly Havendri, Irfan Arnif, 2010, Kaji Eksperimental Penentuan Sudut Ulir Optimum Pada Turbin Ulir Untuk Data Perancangan Turbin Ulir Pada Pusat Listrik Tenaga MikriHidro (PLTMH) dengan Head Rendah, Universitas Andalas, Padang. 